JAMP: Jurnal Adminitrasi dan Manajemen Pendidikan

Volume 1 Nomor 3 September 2018, Hal : 347-357

Tersedia Online di http://journal2.um.ac.id/index.php/jamp/

ISSN 2615-8574 (online)

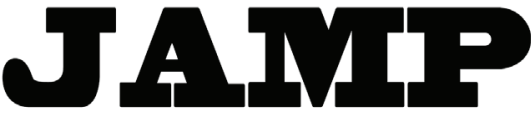

JURNAL ADMINISTRASI DAN MANAJEMEN PENDIDIKAN

\title{
MANAJEMEN PENANGANAN BURNOUT DALAM MENINGKATKAN KINERJA TENAGA ADMINISTRASI SEKOLAH
}

\author{
Iva Dwi Hartanti \\ Achmad Supriyanto \\ Nurul Ulfatin \\ ivadheha@gmail.com \\ Universitas Negeri Malang, Jl. Semarang No. 5 Malang 65145
}

\begin{abstract}
This study aims to determine the implementation of burnout management to improve the performance of TAS in high school. This study uses a qualitative descriptive method with a type of case study. The collection of data using in-depth interviews, observation and documentation. Data sources of researchers came from principals, laboratory staff, financial staff, caraka, security guards and sub-heads of TU. Data analysis was carried out with data condensation, data display and verification processes. The results of this study (1) TAS showed symptoms of physical and psychological fatigue, decreased morale, complaining about oneself, emotional uncertainty, and feelings of cynicism, (2 ) type of burnout is fatigue and saturation in work, keeping distance from the environment, emotions are more sensitive, (3) causes of burnout are two factors, external factors and internal factors, (4) procedural steps in handling burnout using the management process starting from planning, organizing, implementation and evaluation, (5) the impact of management on burnout handling, namely a sense of kinship between TAS employees, building friendships, preventing misunderstandings, being more prepared to carry out tasks, and being more disciplined in carrying out tasks and activities.
\end{abstract}

Keywords: Burnout, Performance, TAS

\begin{abstract}
Abstrak: Penelitian ini bertujuan untuk mengetahui pelaksanaan manajemen penanganan burnout untuk meningkatkan kinerja TAS di Sekolah Menengah Atas. Penelitian ini menggunakan metode deskriptif kualitatif dengan jenis studi kasus. Pengumpulan datanya menggunakan wawancara mendalam, observasi dan dokumentasi. Sumber data peneliti berasal dari kepala sekolah, laboran, staf keuangan, caraka, satpam dan kasubag TU. Analisis data dilakukan dengan proses kondensasi data, display data, dan verifikasi. Hasil penelitian ini (1) TAS menunjukkan gejala kelelahan secara fisik dan psikologis, semangat kerja menurun, mengeluh pada diri sendiri, emosional yang tidak menentu, dan terdapat perasaan yang sinisme, (2) jenis burnout yaitu kelelahan dan jenuh dalam bekerja, menjaga jarak dengan lingkungan, emosi yang lebih sensitif, (3) penyebab burnout ada dua faktor yaitu faktor ektern dan faktor intern, (4) langkah prosedural dalam manajemen penanganan burnout menggunakan proses manajemen dimulai dari perencanaan, pengorganisasian, pelaksanaan dan evaluasi, (5)dampak manajemen penanganan burnout yaitu rasa kekeluargaan antara pegawai TAS, membangun silaturahmi, mencegah kesalahpahaman, lebih siap menjalankan tugas, dan lebih disiplin dalam menjalankan tugas maupun kegiatan.
\end{abstract}

Kata kunci: Burnout, Kinerja, TAS

Rasa lelah sering dijumpai saat melakukan pekerjaan. Dalam menjalani pekerjaan seringkali pegawai mengalami kelelahan fisik ataupun mental. Hal tersebut sejalan dengan pendapat Leksono (2014) bahwa rasa jenuh dalam bekerja merupakan faktor dalam meningkatkan stres dan menurukan kinerja karyawan. Penderita banyak ditemukan pada anggota pelayanan umum seperti polisi, guru, perawat bahkan Tenaga Administrasi Sekolah (TAS). Burnout yang terjadi menimbulkan jenuh dalam bekerja sehingga dapat 
membatasi ruang mereka dalam bekerja. Setiap sekolah mempunyai visi dan misi dalam melaksanakan tujuan pendidikan, maka di butuhkan tenaga ahli untuk membantu terlaksananya tujuan tersebut. Dalam hal ini TAS sebagai pendukung terlaksananya kegiatan sekolah harus memberika pelayanan maksimal kepada masyarakat khususnya konsumen pendidikan.

TAS merupakan tenaga non-pendidik disekolah, misalnya petugas administratif, laboran, hingga pustakawan. TAS merupakan personil yang memiliki peran dan tanggungjawab dalam mewujudkan kelancaran kegiatan pendidikan, peran TAS sebagai pendukung dan pelayanan dalam proses kegiatan sekolah. Oleh karena itu TAS bukan hanya sebagai pengelola administrastif tetapi juga sebagai tenaga ahli dapat menjalankan profesionalitasnya di bidangnya masing-masing. Pekerjaan yang monoton dan timbulnya rasa stres membuat TAS mengalami burnout yang dapat menurunkan kinerja pegawai.

Peneliti memillih salah satu Sekolah Menengah Atas (SMA) di Malang. karena melihat dari beberapa program unik yang tidak ada di sekolah lain mengenai manajemen penanganan burnout. Sekolah berhasil membuat kegiatan yang membuat TAS tidak mengalami burnout dalam bekerja. Sekolah ini mengutamakan asas kekeluargaan dan sharing terhadap pekerjaan. Karena dengan rasa kekeluargaan dan kedekatan, TAS tidak merasa tertekan dalam menjalani pekerjaan yang tentunya terdapat deadline tugas. Dari 10 sekolah SMA Negeri di Kota Malang, sekolah ini yang berhasil membuat TAS tetap profesional dalam mengerjakan tugasnya. Sekolah Menengah Atas (SMA) merupakan sekolah yang memberikan pelayanan maksimal kepada konsumen pendidikan dengan turut melaksanakan manajemen sumber daya manusia dengan baik, yaitu dengan membuat sistem manajemen penanganan burnout.

Sekolah Menengah Atas (SMA) di Malang mempunyai program manajemen penanganan burnout, seperti apel pagi, kegiatan berkunjung ke rumah anggota TAS, olahraga, piket dan refreshing. Upacara, apel pagi, olah raga dan piket dapat mengatasi burnout dalam hal pekerjaan, sedangkan di luar itu ada kunjungan ke rumah anggota TAS dan refreshing. Manajemen penanganan burnout ini mewadahi anggota TAS secara umum untuk sharing terkait tugas dan masalah, mulai dari perencanaan hingga evalusi tugas atau kegiatan yang telah dilaksanakan. Selain itu kegiatan ini dapat mengedukasi TAS untuk memiliki tanggung jawab yang besar dalam melaksanakan tugasnya membantu terselenggaranya pendidikan yang berkualitas. Hal ini dilakukan agar terdapat sinergi antara anggota TAS ketika di sekolah dan di luar sekolah dengan azas kekeluargaan. Dengan harapan, rasa kekeluargaan di sekolah dalam bekerja dapat mengimbangi rasa stres dan jenuh di sekolah sehingga TAS dapat fokus terdahap pekerjaan yang dilakukan.

Robert Kreitner dalam Badan Kepegawaian Negara (2016) mengatakan bahwa burnout merupakan kondisi yang muncul dari waktu ke waktu yang ditandai dengan kelelahan emosional dan sesuatu kombinasi sikap-sikap negatif. Burnout merupakan istilah psikolosis di dunia kerja ketika individu mengalami kelelahan berkepanjangan dan penurunan minat bekerja. Pines dan Aronson mendefinisikan burnout sebagai kelelahan secara fisik, emosional, dan mental sebagai akibat dari keterlibatan diri dalam jangka waktu yang panjang terhadap situasi yang penuh dengan tuntutan emosional. Burnout merupakan proses psikologis yang dihasilkan oleh stres yang tidak terlepaskan dan menghasilkan kelelahan emosi, perubahan kepribadian, dan perasaan pencapaian terhadap diri yang menurun.

Manajemen burnout seringkali diartikan sempit yang hanya sebatas mengurangi rasa lelah dan jenuh dalam menjalani pekerjaan. Padahal dengan manajemen burnout yang baik dapat mengatasi masalah kerja dan meningkatkan kinerja TAS sebagai pelayan pendidikan. Manajemen burnout di bentuk oleh anggota TAS salah satu Sekolah Menengah Atas (SMA) yang mengarah pada sistem kekeluargaan. Manajemen burnout terdiri dari dua kata, yaitu manajemen dan burnout, manajemen mengarah kepada proses, cara mengatasi masalah dan solusi, sedangkan burnout yaitu keadaan yang dapat mengakibatkan stres dan jenuh dalam bekerja. Apabila disimpulkan, tujuan dari manajemen burnout ini adalah agar anggota TAS tidak mengalami burnout dalam bekerja sehingga tidak mengganggu dalam melaksanakan tugas yang dikerjakan.

Menurut Maslach,dkk (dalam Haryanti: 2013), burnout mempunyai tiga dimensi yaitu (1) kelelahan (exhaustion) merupakan dimensi burnout yang ditandai dengan perasaan letih berkepanjangan baik secara fisik, (2) depersonalisasi/cynicism, tolak ukur depersonalisasi adalah berkembangnya sikap 
negatif dan perasaan yang negatif terhadap penerima pelayanan, (3) reduced personal accomplishment ialah adanya perasaan yang tidak puas terhadap diri sendiri, pekerjaan hingga pekerjaan. Faktor-faktor penyebab stres pada karyawan atau pegawai menurut Hasibuan(2016) adalah beban kerja yang sulit dan berlebihan, tekanan dan sikap pimpinan yang kurang adil dan wajar, waktu dan peralatan kerja yang kurang memadai, konflik pribadi dengan pimpinan atau kelompok kerja, balas jasa yang terlalu renda dan masalah keluarga. Menurut Pines dan Aronson mengatakan bahwa faktor burnout adalah faktor dari lingkungan kerja dan faktor individu.

Sekolah harus berjalan sesuai dengan misi dan visi yang telah ditentukan. TAS sebagai salah satu pendukung harus memiliki kinerja yang bagus. Salah satu cara untuk meningkatkan kinerja yaitu dengan manajemen penanganan burnout yaitu mengatur bagaimana pegawai TAS tetap bekerja pada koridor yang telah di tentukan dan meningkatkan kinerja TAS. Sekolah perlu memikirkan psikologis dan mental para pegawai TAS sebagai pendukung terselenggaranya pendidikan. Selain itu TAS juga berhak mendapatkan kesejahteraan sosial yang pantas dan memadai, pengahargaan sesuai tugas dan prestasi kerja yang telah di tentukan. Dengan kata lain manajemen penanganan burnout memiliki peran yang penting untuk menghidupkan dan semangat kerja pegawai TAS yang diharapkan dapat meningkatkan kinerja pegawai TAS dalam melayani konsumen pendidikan. Apabila hal tersebut dilaksanakan, maka tugas yang diberikan akan berhasil sesuai dengan yang direncanakan.

Kinerja merupakan salah satu aspek yang menjadi perhatian bagi suatu organisasi maupun sebuah instansi. Pegawai tersebut yang bekerja langsung di bawah naungan sebuah organisasi atau instansi memiliki andil dalam membangaun dan membentuk citra dan repustasi tempat dimana ia bekerja (Badri,2017). Maka dari padaitu, kinerja menjadi salah satu unsur yang penting dalam membantu kinerja sebuah organisasi atau instansi. Menurut penelitian yang dilakukan oleh Dita Novita dalam Badri (2017), menguangkapkan bahwa sebuah organisasi atau instansi yang ingin tetap unggul memburuhkan Sumber Daya Manusia (SDM) dengan kinerja yang tinggi agar memungkinkan instansi dalam menjaga stabilitasnya. Dengan begitu sekolah juga membutuhkan kinerja yang tinggi dan maksimal dari tenaga non-pendidik yaitu TAS. kinerja TAS ini nantinya dapat membantu sekolah dalam mampu bersaing dan tetap unggul dalam modernisasi saat ini. Sehingga di perlukan langkah yang tepat dalam mengelola SDM dengan memperhatikan proses manajemen. Menurut Fattah (2008) mengemukakan bahwa manajemen diartikan sebagai proses merencana, mengorganiasi, memimpin dan mengendalikan upaya organisasi dengan segala aspek agar tujuan organisasi tercapai secara efektif dan efisien. Oleh karena itu manajemen dalam melakukan suatu aktifitas dalam kehidupan harus dilakukan guna mencapai ketercapaian tujuan. Dalam melaksanakan fungsi manajemen suatu organisasi harus melaksanakan perencaanaan, pengorganisasian, pelaksaan, pengawasan dan evaluasi.

Peran TAS sangat besar dalam proses pendidikan. Peran tersebut akan sangat efektif apabila terjadi suatu proses yang di organisasikan sebagaimana yang dilaksanakan salah satu SMA di Malang yakni dengan melakukan manajemen penanganan burnout. Dengan adanya manajemen penanganan burnout, TAS memiliki wadah untuk menghadapi suatu permasalahan bekerja dan menyelesaikan secara bersama serta sebagai hiburan yang tepat saat bekerja bersama keluarga TAS. Oleh karena itulah peneliti tertarik untuk melakukan penelitian mengenai manajemen penanganan burnout salah satu SMA di Malang ini sebagai wujud dalam meningkatkan kinerja TAS.

\section{METODE}

Penelitian ini dilaksanakan dengan menggunakan pendekatan kualitatif, sehingga peneliti dapat menemukan cara me-manage burnout TAS di SMAN 5 Malang. Sugiyono (2013) menjelaskan "penelitian kualitatif adalah penelitian yang digunakan untuk meneliti pada kondisi yang alamiah (sebagai lawannya adalah eksperimen), di mana peneliti adalah sebagai instrumen kunci".

Kehadiran peneliti diketahui secara penuh oleh warga sekolah. Peneliti mengikuti secara langsung beberapa kegiatan yang dilaksanakan mengenai manajemen penanganan burnout dalam meningkatkan kinerja TAS. Peneliti juga melakukan pendekatan dan pengenalan terhadap kepala sekolah, kasubag TU dan seluruh anggotas TAS. 
Lokasi penelitian di Jalan Tanimbar 24 Malang. Sumber data diperoleh dari kata-kata, tindakan, dan dokumentasi. Sumber data berupa kata-kata diperoleh dari kegiatan wawancara dengan beberapa subjek penelitian. Peneliti menggunakan informan kunci untuk memperoleh data ketika melakukan wawancara yaitu Ibu Tutik Kusmini, karena beliau selaku Kasubag Tata Usaha SMAN 5 Malang. Sumber data lain yang membantu peneliti dalam memperoleh informasi yaitu: (1) kepala sekolah, (2) kepala TU, (3) laboran, (4) staf keuangan, (5) caraka, (6) satpam. Selain itu, sumber data berupa tindakan berasal dari orang-orang atau suatu hal yang menjadi subjek penelitian yang diamati oleh peneliti secara langsung, dan dilengkapi dengan dokumen, seperti profil sekolah, foto kegiatan penanganan manajemen burnout, struktur organisasi TAS, dan dokumen lainnya yang terkait dengan manajemen penanganan burnout di SMAN 5 Malang.

Teknik yang digunakan untuk mengumpulkan data berupa wawancara, observasi, dan dokumentasi. Proses untuk menganalisis data yang digunakan adalah melakukan kondensasi data, penyajian data dalam bentuk naratif teks, kemudian ditarik kesimpulan (Miles, Huberman, Saldana: 2014). Cara yang digunakan untuk mengecek keabsahan data adalah triangulasi sumber data dan teknik, kecukupan bahan referensi, perpanjangan pengamatan, dan pengecekan anggota.

\section{HASIL}

\section{Gejala dan Jenis Burnout}

Berdasarkan hasil penelitian yang dilakukan oleh peneliti, gejala yang timbul menampakkan bahwa sering dialami oleh pegawai yang memiliki kemauan dan semangat untuk bekerja, yang dalam hal ini mereka selalu menuntut diri untuk selalu terfokus pada satu pekerjaan agar hasilnya baik. Tetapi gejala yang muncul seperti kelalahan secara fisik, psikologis, mengeluh pada diri sendiri dan menurunnya semangat kerja perlu di tangani secara benar agar tidak merugikan bagi mereka dan organisasi atau sekolah. Gejala tersebut juga akan mempengaruhi mood atau suasana hati.

Jenis burnout merupakan bentuk yang nampak pada seseorang yang mengalami burnout, seperti mereka mengekspresikan burnout dalam beberapa hal. Setiap orang berbeda tetapi mengarah pada hal yang sama yaitu mengarah pada emosi yang tumpul, keputusasaaan dalam mengerjakan, kurangnya motivasi hingga ketidakstabilan secara emosional. Burnout selalu menampilkan bentuk lelah dalam bekerja. Dalam hal tersebut dapat dapat dijelaskan bahwa jenis burnout yang terjadi pada pegawai Sekolah Menengah Atas adalah kelelahan dan jenuh dalam bekerja. Jenis tersebut mempengaruhi pada proses kinerja mereka. Hal tersebut menjelaskan bahwa dalam jenis burnout ini dapat menurunkan prestasi dalam diri seseorang seperti kompetensi diri, motivasi kerja dan produktifitas kerja. Hal terseut juga akan mempengaruhi pegawai lebih mudah lelah dan sensitif terhadap apaupun yang menyinggung perasaan. Sehingga burnout mempunyai gejala-gejala yang akan mempengaruhi pada jenis burnout yang di tampakkan. Sehingga dengan gejala-gejala yang muncul dapat di atasi dengan manajemen penenganan burnout. Dengan hal tersebut diharapkan mampu mencegah atau mengeurangi dampak negatif dari burnout.

\section{Faktor-faktor dari burnout}

Faktor penyebab burnout muncul akibat keterbatasanan ruang dalam bekerja. pegawai mempunyai daerah atau wilayah kerja sendiri untuk melakukan pekerjaan, sehingga mereka jenuh dan bosan dengan lingkungan yang monoton. Penyebab burnout tidak hanya dari faktor ektern, tetapi juga dari faktor intern. Faktor intern ini bisa mempengaruhi kondisi dan psikologi pegawai saat bekerja. faktorn intern ini dapat membuat pegawai merasa depresi, hingga bersikap acuh tak acuh. Dalam bekerja apabila dalam melayani konsumen pendidikan harus selalu prima dalam bekerja. Faktor penyebab burnout dapat dibedakan menjadi 2 bagian yaitu faktor intern dan faktor ektern. Faktor intern di pengaruhi atau terjadi akibat dalam diri sedangkan, faktor ektern terjadi akibat dari faktor yang berasal dari lingkungan sekitar. Faktor intern dapat mempengaruhi seseorang dari dalam diri seorang pegawai.

Beda halnya dengan hal tersebut di atas, ternyata yang menjadi faktor yang mendominasi penyebab 
burnout apabila diberikan perbandingan antara faktor intern dan faktor ektern. Dalam manajemen penyelesaian burnout lebih dominan pada faktor penyebab intern. faktor yang mendominasi penyebab burnout adalah dari faktor intern, yang ditimbulkan dari seorang individu itu sendiri. Penyebab burnout dari faktor internal ini disebabkan dari ketidakberdayaan seorang individu dalam mengontrol emosional dalam diri. Hal ini dapat muncul karena adanya kurangnya motivasi, cita-cita dan harapan yang diinginkan. Sehingga untuk mengurangi dampak dari faktor penyebab burnout harus adanya dukungan dari sesama anggota TAS dan pimpinan untuk saling memotivasi.

\section{Langkah Prosedural dalam Manajemen Penanganan Burnout}

Hal pertama yang dilaksanakan oleh sekolah dalam penyelenggaraan manajemen penanganan burnout adalah dengan melakukan musyawarah atau rapat antara pegawai TAS. Dimulaidari perencanaan pengurus, program kegiatan, perkiraan waktu dan sebagainya. Manajemen penanganan burnout ini dicetuskan oleh pegawai TAS yang kemudian di bentuk oleh kepala sekolah. Manajemen penanganan burnout di bentuk oleh pegawai TAS. Begitu halnya dengan program kegiatan di dalamnya, mereka membentuk sendiri program kerja beserta dengan perencanann waktunya. Perencanaan program kegiatan manajemen penanganan burnout memilih waktu yang tepat untuk pelaksanaannya, yakni waktu dimana semua anggota bisa berkumpul dan tidak mengganggu kegiatan lain di sekolah. Pada perencanaan program dibahas secara bersama-sama secara musyawarah oleh seluruh anggota TAS. Hal tersebut dilaksanakan agar manajemen penanganan burnout mendapatkan saran dan masukan dari anggota yang lain mengenani program dan perencanaannya. Selain itu ketika pegawai TAS secara bersama-sama membuat program dengan niat, maka harus dijalankan secara komitmen. Selain itu dalam menjalankan suatu program kegiatan yang tidak ada tata tertib yang tertulis mereka tentunya juga harus saling mendukung satu sama lain, sehingga mereka juga menciptakan rasa kekeluargan antara pegawai TAS. Program kegiatan yang diselenggarakan oleh manajemen penanganangan burnout mengarah kepada penanganan burnout pegawai, sehingga kegiatan yang dibuat juga ringan tetapi dapat menimbulkan manfat yang besar bagi pegawai tersebut.

Tidak ada pengurus secara menyeluruh secara formal, tetapi dalam kepengurusannya menjadi satu dengan struktur organisasi TU. Tetapi dalam pelaksanannya beberapa program dibuat susunan panitia untuk mempermudah jalankanya kegiatan. Penyususnan pengurus manajemen penanganan burnout di tentukan langsung oleh anggota TAS dan diminta persetujuan kepada kepala TU dan kepala sekolah. Dalam setiap program kerja memiliki struktur pengurus yang terdiri dari ketua, bendahara, sekretaris atau notulen, sie humas, sie acara dan sie konsumsi.

Kepala TU dan pegawai TAS menyampaikan program kegiatan yang telah di rencakan kepada kepala sekolah. Kemudian mengadakan musyawarah atau pertemuan untuk membahas bersama-sama dengan kepalas sekolah. Kepala TU menyampaikan program kegiatan yang di setujui oleh kepala sekolah. Dalam setiap program kegiatan mempunyai koordinator untuk memimpin atau mempertanggungjawabkan. Kepala TU dan pegawai TAS melaksanakan program kegiatan yang telah disetujui.

Evaluasi rutin Manajemen penanganan burnout dilaksanakan setiap minggu dan akhir bulan oleh kepala TU dan kepala sekolah. Evaluasi dilakukan secara bersama-sama pada saat pelaksanaan program kegiatan. Aspek-aspek yang perlu dievaluasi dalam manajemen penanganan burnout dimulai dari komitemen pegawai TAS sampai hasil kinerja mereka.

\section{Dampak Manajemen Penanganan Burnout}

Manajemen penanganan burnout memiliki manfaat untuk meningkatkan kinerja pegawai TAS, karena sebagaimana diketahui bahwa burnout lebih mendominasi muncul dari individu itu sendiri sehingga dengan adanya berbagai program dapat memunculkan manfaat bagi para anggota TAS di Sekolah Menengah Atas. Sekolah Menengah Atas ini menggunakan asas kekeluargaan untuk lebih mempererat sesama pegawai TAS. Kedekatan antar sesama pegawai TAS dapat mengurangi beban pekerjaan dan agar lebih termotivasi dalam bekerja. Manajemen penanganan burnout dapat mendorong semangat pegawai TAS untuk tetap bekerja sesuai dengan tugas dan fungsingnya. Dengan adanya program dari manajemen penanganan burnout pegawai terhindar dari sifat yang egois dan individualisme 
terhadap pekerjaan dan lingkungan sekitarnya.Bahwasanya manajemen penanganan burnout merupakan program yang dapat meningkatkan kinerja pegawai. Dengan adanya adanya manajemen penanganan burnout pegawai bisa lebih berfikir positit dan menjalankan aspek-aspek profesionalitas dalam bekerja. Berdasarkan hasil tersebut, dapat di ilustrasikan pada Gambar 1.

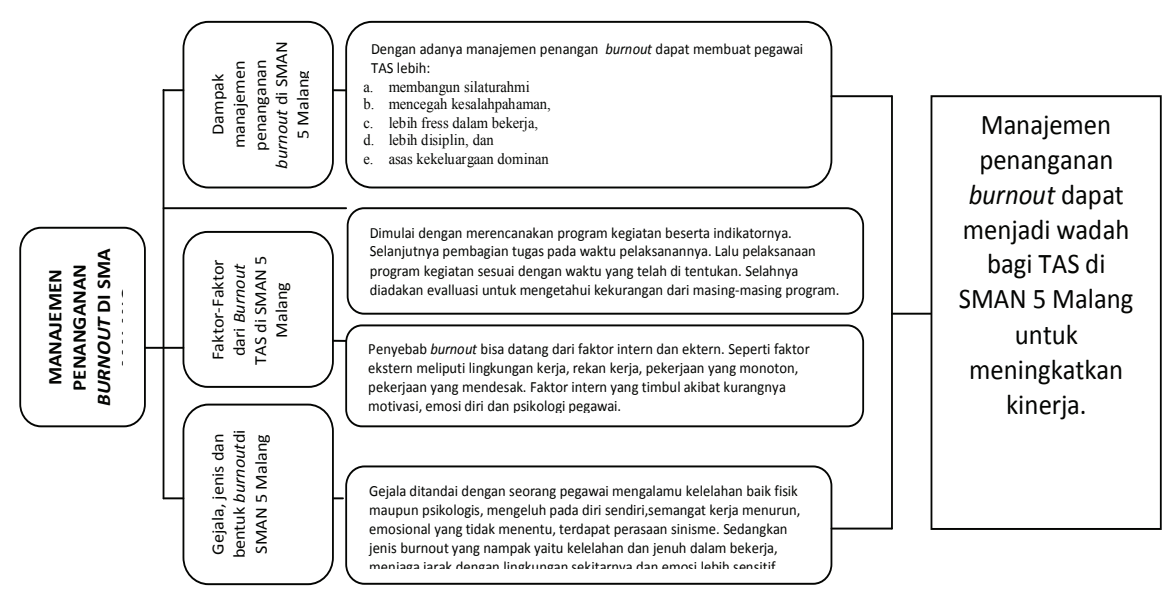

Gambar 1 Skema Akhir Manajemen Penanganan Burnout di Sekolah Menengah Atas

Berdasarkan Gambar 1 dijelaskan bahwa dalam manajemen penanganan burnout terdapat beberapa fokus yang harus di perhatikan yaitu mulai dari mengidentifikasi gejala, jenis dan betuk dari burnout. kemudia harus mengetahui faktor-faktor yang menjadi penyebab burnout sehingga kita bisa menentukan langkah atau prosedur dalam menanganinya. kemudian kita menentukan langkah prosedural dalam manajemen penanganan manajemen burnout menggunakan proses manajemen dari perencanaan, pengorganisasian, pelaksanaan dan evaluasi. dari hal tersebut tentu di dapatkan dampak positif dari manajemen tersebut yaitu dengan rasa kekeluargaan, keakraban antara pegawai TAS.

\section{PEMBAHASAN}

\section{Gejala dan Jenis Burnout}

Gejala burnout yang nampak di Sekolah Menengah Atas ini terlihat pada pegawai yang awalnya memiliki kemauan dan semangat kerja yang tinggi. Tetapi, karena mereka selalu di tuntut dengan pekerjaan yang salalu diulang dan tidak adanya inovasi pekerjaan, maka mereka cenderung akan bosan dan jenuh dalam bekerja. Dengan itu, akan menyebabkan kondisi pegawai tidak akan maksimal dalam menjalankan tugasnya. Di Sekolah Menengah Atasterdapat beberapa kecenderungan gejala burnout yang terlihat yaitu mereka kelelahan secara fisik dan psikologis. Penelitian tersebut di perkuat oleh Baron dan Greenberg dalam Rosyid (1996) pertama penderita burnout mengalami kelelahan fisik sehingga mereka akan kekurangan energi dan merasa lelah dalam setiap waktu, kedua, yaitu menyerang psikologis mereka baik berupa kelelahan mental dan dan sikap mereka terhadap lingkungannya.

Secara fisik pegawai akan merasa kelelahah seperti cepat lelah, sedangkan secara psikologis banyak indikator yang dapat mempengaruhinya seperti mengeluh pada diri sendiri. Hal tersebut terjadi ketika mereka sangat optimis dengan apa yang mereka kerjakan berjalan dengan cepat dan lancar, tetapi keadaan sebaliknya. Pekerjaan yang banyak dan menumpuk, serta di tambah dengan deadline yang sudah ada membuat mereka terbebani secara psikologis dan mengeluh pada diri sendiri, dan hal tersebut juga yang tidak membuat pekerjaan mereka cepat selesai.

Gejala yang selanjutnya adalah gejala yang dilihat dari semangat kerja pegawai yang menurun. Hal ini dapat di tandai dengan kegiatan atau aktivitas mereka yang menurun, pegawai lebih sering berdiam diri dan tidak tertarik dengan apa yang sudah menjadi tugas mereka dalam bekerja. Mereka tidak semangat dalam melakukan aktivitas di lingkungannya termasuk menunda pekerjaan, menghindari diskusi dengan rekan kerja. Selain itu gajela burnout yang 
muncul adalah masalah emosional yang tidak menentu, hal ini masih ada hubungannya dengan lelah secara psikologis mengenai perilaku dan mental manusia secara ilmiah. Emosional yang tidak menentu ini juga mempengaruhi reaksi mereka dalam bekerja. Pegawai akan lebih sensitif dengan perasaannya seperti cepat marah dan sering kesal, bersikap sinisme dan merasa curiga dengan apa yang ada di lingkungannya, terdapat perasaan gagal di dalam diri pegawai. Hal tersebut bentuk dari emosional yang muncul dari pegawai. Dalam hal ini gejala burnout yang muncul di Sekolah Menengah Atas tidak menunjukkan pada kondisi burnout yang ekstream atau akut.

Gejala tersebut sesuai dengan yang di ungkapkan oleh Freudenberger dan Richelson dalam Farhati \&Haryanto (1998) bahwa terlibat beberapa gejala pada penderita burnout yakni kelelahan dari proses kehilangan energi di sertai keletiham, lari dari kenyataan yaitu alat untuk menyangkal penderitaan yang alami, kebosanan dan sinisme yaitu penderita merasa tidak tertarik lagi terhadap tugas yang di kerjakan, emosional yaitu penderita mampu mengerjakan dengan cepat dengan menurunnya kemampuan mengerjakan pekerjaan secara cepat, akan menimbulkan gelombang emosional pada diri individu, merasa tidak di hargai, masalah psikosomatis, curiga tanpa alasan, depresi dan penyangkalan kenyataan akan keadaan dirinya sendiri. Dari pernyataan tersebut terdapat beberapa kesamaan antara gejala yang timbul di Sekolah Menengah Atasdengan teori,sehingga untuk penanganannya lebih lanjut juga bisa diidentifikasikan dengan baik.

Bentuk burnout yang tampak pada Sekolah Menengah Atasini menunjukkan ada beberapa tipe seperti lelah dan jenuh dalam bekerja. Dalam bentuk ini pegawai merasa energi atau motivasi dalam bekerja sedang menurun, sehingga pegawai merasa lelah dalam melakukan pekerjaan biasa dilakukan. Selain itu bentuk bunout yang terlihat di Sekolah Menengah Atasadalah menjaga jarak dengan lingkungan yang ada di sekitanya. Jenis ini terjadi ketika para pegawai mengalami jenuh dan ingin sendiri dalam. Jenis selanjutnya yaitu emosional lebih sensitif hal ini kaenakan pegawai menekan terhadap dirinya sendiri, mengeluh pada diri sendiri sehingga hal tersebut dapat menimbulkan sinisme dan rasa curiga terhadap apa yang di sekelilingnya.

Penelitian ini selaras dengan pendapat Maslach, dkk dalam Ranny (2013) dengan keberadaan di lapangan yaitu burnout membentuk suatu penampakan burnout yaitu berbentuk dalam bentuk kelelahan dan bosan dalam bekerja, Depersonalisasi/Cynicism yaitu cenderung untuk menjaga jarak dengan orang lain, menarik diri dari lingkungan sosial dan cenderung tidak peduli dengan lingkungan serta individu yang ada di lingkungan tersebut, kemudian lain yang terlihat yaitu emosi yang lebih sensitf, hal ini di tunjukkan juga atas bentuk dari kelanjutan dari kelelahan emosi yang menacu pada terkurasnya dan kerkurangnya sumberdaya emosional. Terdapat beberapa kondisi yang menyatakan kelelahan emosi seperti perasaan frustrasi, sedih, putus asa, hampa tertekan, mudah tersinggung, merasa terbebani dengan tugas yang ada, mudah marah tanpa alasan yang jelas sehingga menimbulkan perasaan seseorang tidak mampu memberikan pelayanan psikologis.

\section{Faktor-faktor Penyebab Burnout}

Penyebab utama dalam burnout adalah pekerjaan yang monoton yang akan berdampak pada kurangnya motivasi pegawai. Dalam hal ini penyebab burnout muncul dari beberapa situasi yang berbeda seperti dari faktor ektern dan faktor intern. Dalam masing-masing faktor mempunyai beberapa penyebab tersendiri, misalnya pada faktor ektern yaitu faktor penyebab burnout yang berasal dari luar diri pegawai. Faktor ini berasal dari lingkungan kerja pegawai, rekan kerja tempat kerja dan yang lainnya yang bukan berasal dari diri sendiri. Lingkungan dari pegawai tersebut dapat mempengaruhi penyebab burnout baik secara langsung maupun 
tidak langsung, karena hal tersebut juga berhubungan dengan apa yang ada di sekitarnya seperti tempat kita melakukan pekerjaan itu sendiri, ataupun lingkungan secara umum seperti lingkungan dimana kita bekerja. Faktor tersebut dapat mempengaruhi penyebab burnout karena pegawai dalam bekerja tidak hanya bekerja sendiri tetapi juga harus bekerjasama dengan orang lain. Sehingga di perlukan hubungan atau keterkaitan dengan orang lain.

Faktor yang berikutnya adalah faktor intern. Faktor ini muncul dari dalam diri pegawai itu sendiri. Misalnya mengenai motivasi dan emosi. Seseorang pegawai harus mempunyai semangat dan motivasi yang kuat, jika motivasi dan semangat itu berkurang akan berdampak juga pada organisasi sebagai lembaga yang menaungi kita bekerja. Faktor ini tumbuh karena setiap manusia mempunyai karakteristik, kepribadian, tingkah laku yang berbeda-beda dengan orang yang lainnya. Seperti ketika seseorang sama-sama diberi motivasi tetapi motivasi tersebut tidak sama dalam mempengaruhi setiap orang, ada yang biasa saja, sedang dan sangat mempengaruhi. Hal tersebut menunjukkan bahwa seorang menunjukkan cara yang berbeda dalam menyikapi suatu hal.

Pada penelitiaan ini selaras dengan ungkapan dari Baron dan Greenberg dalam Mutiasari (2010) yang menyatakan bahwa terdapat dua faktor yang mempengaruhi burnout yaitu faktor ekternal dan internal. Dimana pada faktor ekternal meliputi kondisi kerja, aturan pekerjaanm prosedur kerja yang mengarah pada faktor yang muncul dari luar diri seorang pegawai. Sedangkan untuk faktor internal yang berasal dari dalam diri seorang pegawai itu sendiri. Selain itu pendapat dari Sulivan dalam Swasti (2017) bahwa burnout dapat disebabkan oleh faktor individu, lingkungan dan budaya. Pekerjaan yang tidak sesuai dengan bidang keahlian juga dapat memicu terjadinya burnout. Begitu pula dengan peran ganda, seorang wanita yang berperan sebagai pekerja dan ibu rumah tangga akan lebih berpotensi mengalami burnout. Faktor lainnya adalah beban kerja yang berlebihan, meliputi lamanya jam kerja, banyaknya tanggungjawab yang harus diterima, dan banyaknya tugas yang harus diselesaikan. Keterlibatan terhadap pekerjaan, tingkat fleksibilitas waktu kerja, dan dukungan sosial juga mempengaruhi terjadinya burnout (Swasti, 2017). Selain faktor lingkungan, burnout juga dipengaruhi oleh faktor individu seperti jenis kelamin, usia, etnis, status perkawinan, tipe kepribadian, konsep diri, dan kemampuan mengendalikan emosi.

\section{Langkah Operasional Manajemen Penanganan Burnout untuk Meningkatkan Kinerja TAS}

Perencanaan merupakan tahap yang paling penting dala suatu kegiatan terutama dalam menghadapi suatu kegiatan. Sebelum memulai suatu kegiatan salah satu SMA di Malang menetapkan terlebih apa yang akan dicapai dan tujuannya. Dalam hal ini juga manajemen penanganan burnout menentukan program kegiatan yang akan dilaksanakan. Hal tersebut selaras dengan pendapat Sudjana (2004) bahwa perencanaan berkaitan dengan rangkaian tindakan atau kegiatan yang akan dilaksanakan untuk mencapai tujuan dimasa yang akan datang. Selanjutnya pada fungsi pengorganisasian, menentukan pengurus dan membentuk jobdisk atau tugas bagi para pengurus dan anggota dalam masing-masing program kegiatan. Selanjutnya pada fungsi penggerakan, para pemimpin sekolah yaitu kepala sekolah dan atasan TAS yakni kepala TU ikut andil untuk terus menyemangati pengurus dan anggota serta memberikan dukungan apabil adlam hal ini manajemen penanganan bunrout mengalami penurunan motivasi. Fungsi pengorganisasian dalam hal ini manajemen penanganan burnout tidak berjalan sendiri dalam melaksanakannnya. Namun melibatkan semua anggota TAS dan kepala sekolah.

Fungsi pengarahan yakni sekolah tetap melakukan pengarahan melalui kepala TU dan kepala sekolah secara langsung. Terakhir fungsi pengawasan yang dilaksanakan oleh sekolah dan kepala TU dengan melakukan evaluasi pada akhir minggu dan akhir bulan secara keseluruhan. Pada pelaksanaan program manajemen penanganan burnout selama ini,berjalan dengan lancar. Namun demikian perlu 
adanya penguatan atau motivasi agar para anggota TAS di satu SMA di Malang tetap menjalankan program dengan baik dan lancar. Dalam pelaksanaanya telah merapkan fungsi manajeme dengan baik yakni mulai fungsi perencanaan hingga fungsi evaluasi. Sesuai dengan menurut Bush \& Mariane (2006) mengatakan bahwa manajemen merupakan suatu usaha untuk mencapai tujuan melalui orang lain yang dilaksanakan dengan cara kerjasama dalam suatu organisasi.

Diperlukan strategi untuk membuat para anggota TAS tetap semangat dalam menjalankan program. Pada program manajemen penanganan burnout memberikan solusi dengan mengadakan beberapa program yang menarik dan santai dengan diisi kegiatan yang banyak manfaat seperti sharing pengalaman dan berdiskusi dengan asas kekeluargaan. Harapannya, agar anggota TAS dapat intens bertemu dan memanfaatkan waktu tersebut dengan sebaik baiknya. Dengan adanya kegiatan tersebut. Dengan adanya kegiata tersebut, maka hal tersebut dapat menjadi daya tarik untuk anggota TAS lebih aktif dalam kegiatan tersebut. Salah satu program kegiatan dilaksanakan pada setiap hari selasa sampai jumat, selain itu ada beberapa jadwal kegiatan yang dilaksanakan setiap satu bulan sekali. Hal ini dapat menambah nilai plus bagi mereka, karena dengan asas kekeluargaan tersebut mereka bisa akrab dan dapat mengurangi dari terjadi burnout dan dapat meningkatkan kinerja dalam berbagi pengalaman dan mengatasi gejala-gejala burnout.

Penelitian tersebut selaras dengan penelitian dari Mutiasari (2010) bahwasanya dalam menghindari atau mengatasi burnout perlu beberapa tindakan seperti pengendalian emosi, berfikir posisitif, dan saling adanya dukungan dari orang lain lain. selain itu Campton \& Mc Carthy dalam Rosyid, Haryanto F (1996) menyarankan beberapa usaha yang dpat dilakukan untuk mencegah burnout. Langkah-langkah yang perlu dilaksanakan antara lain job redesign, langkah ini berupa merancang kembali pekerjaan yang ada agar tidak monoton, membosankan dan menimbulkan kelalah fisik maupun psikologis. kemudian performance management ini mengacu pada bagaimana manajemen dapat mempertahankan kinerja yang dapat dicapai oleh organisasi secara optimal. program konsultasi dan umpan balik. kegiatan ini dapat memberi kesempatan pada karyawan untuk berbagi rasa dengan orang lain, dan umpan balik merupakan alat yang digunakan untuk memberikan masaukan-masukan agar seseorang dapat menguarangi perasaan negatif yang dirasakan, dna mengembangkan harga diri yang positif.

Manajemen penanganan burnout dalam pelaksanaannya juga pernah mengalamu beberapa kendala seperti anggota TAS yang tidak hadir atau terlambat datang. Untuk mengurangi hal tersebut maka perlulah dilakukan teknik-teknik khusus untuk menangani itu seperti memotivasi dan saling mengingatkan. Dalam hal ini sesama anggota TAS dituntut untuk bekerjasama dalam menjalankan program yang mereka buat untuk mereka sendiri.

\section{Dampak Manajemen Penanganan Burnout}

Dengan hadirnya manajemen penanganan burnout di salah satu SMA Malang, maka pegawai TAS dapat menangani burnout agar tidak mengganggu pekerjaan mereka. Dengan demikian diharapkan dapat meningkatkan kinerja mereka untuk melayani konsumen pendidikan dengan baik, benar, dan cepat. Hal ini didukung oleh penelitian Pule K. Jankome, M. Mangoriand dan Ms. Guillermina Ritacco dalam Badri (2017) bahwa menunjukkan keterkaitan dalam burnout dan kinerja pegawai dengan indikasi semakin rendah burnout maka semakin tinggi kinerja para pegawai.

Hal ini sesuai dengan tujuannya yaitu untuk mewadahi TAS untuk meningkatkan kinerja mereka dalam asas kekeluargaan. Sehingga diharapkan melalui program ini pegawai lebih bisa memupuk semangat mereka dalam bekerja dengan menangani masalah burnout yang ada hingga mendalam dan agar memperoleh pengalaman yang kaya dan motivasi serta dukungan dari rekan kerja secara maksimal. Apabila dari tujuan tersebut dapat diwujudkan, akan mendapat dampak positif yaitu meningkatkat kinerja mereka. oleh karena itu juga, dukungan dari rekan kerja dan pemimpin tanpa dimintapun akan langsung di penuhi oleh pemimpin mereka. Menurut Wisudaningrum (2015) Penanganan burnout sebenarnya dapat dilakukan oleh individu dan organisasi secara terstruktur, massive dan sistematis, sehingga karyawan yang mengalami burnout tidak perlu merasa sendiri dalam mengatasinya. 


\section{KESIMPULAN}

Berdasarkan paparan data, temuan penelitian dan pembahasan mengenai manajemen penanganan burnout dalam meningkatkan kinerja TAS di Sekolah Menengah Atas dapat disimpulkan bahwa gejala, jenis dan bentuk burnout dalam manajemen penanganan burnout yakni: (1) gejala timbul pada pegawai yang kemauan dan semangat bekerja yang tinggi sehingga kurang bisa mengatur cara kerja mereka, (2) kelelahan secara fisik dan psikologis, (3) mengeluh pada diri sendiri, (4) semangat kerja yang menurun, (5) semangat kerja yang menurun, (6) terdapat perasaaan sinisme. Selain itu juga terdapat tiga jenis burnout yang terlihat yaitu: (1) kelelahan dan jenuh dalam bekerja, (2) menjaga jarak dengan lingkungan sekitarnya, (3) Emosi lebih sensitif.

Penyebab burnout di bagi menjadi dua faktor yaitu faktor intern dan faktor ektern. Adapun faktor intern terdapat penyebab antara lain: (1) kurangnya motivasi, (2) emosional diri, (3) psikologi pegawai. Sedangkan untuk yang faktor ektern yaitu: (1) lingkungan kerja, (2) rekan kerja, (3) pekerjaan yang monoton, dan (4) pekerjaan yang mendesak.

Manajemen dalam pembentukan manajemen penanganan burnout dan program manajemen penanganan burnout dimulai dari perencanaan, yaitu semua anggota TAS melakukan musyawarah bersama pihak yang terlibat seperti kepala sekolah untuk membahas mengenai program kerja yang dilakukan dan pengurus dalam program kerja yang akan di laksanakan. Struktur organisasi secara keseluruhan tidak ada, hanya saja struktur organisasi mengikuti dan sesuai dengan struktur anggota TU. Terdapat tugas masing-masing yang harus di kerjakan. Selanjutnya yaitu pelaksanaan manajemen penanganan burnout, dalam hal ini saling menggerakkan satu sama lain namun tetap berkoordinasi dengan pihak kepala sekolah, yang dalam hal ini akan memberikan pengarahan, motivasi serta dukungannya. Pada akhirnya manajemen penanganan burnout rutin melaksanakan evaluasi program kerja mereka dan pencapaian hasil kinerja mereka setiap minggu dan akhir bulan. Selain itu sekolah mengadakan evaluasi jika pada situasi dan kondisi tertentu.Sampai saat ini keberadaan maupun program dari manajemen penanganan burnout belum pernah berdampak negatif, baik bagi pegawai TAS atau pihak-pihak yang terlibat, dan bagi konsumen pendidikan.

Dampak positif dari keberadaan manajemen penanganan burnout salah satunya adalah sebagai wadah pegawai TAS dalam mengatasi burnout dalam kerja sebagai upaya untuk meningkatkan kinerja yang profesional kental sesama pegawai TAS. Dengan begitu banyak yang di rasakan dalam program manajemen penanganan burnout terdapat manfaat lain yaitu (1) menciptakan rasa kekeluagaan yang kental sesama pegawai TAS, (2) membangun silaturahmi dengan sesama pegawai TAS dan yang terlibat, (3) mencegah kesalahpahaman antar pegawai TAS, (4) lebih segar dalam menjalankan tugas yang dikerjakan, (5) lebih dilatih disiplin dalam melaksanakan tugas, program kegiatan.

\section{DAFTAR RUJUKAN}

Badan Kepegawaian Negara: Kanreg IX Jayapura. Memahami dan Mengatasi Burnout. 2016. Jayapura: Badan Kepegawaian Negara.

Badri, N. A. H. 2017. Hubungan Burnout dengan Kinerja di Kalangan Pustakawan di Universitas Indonesia. (Online), (repository.unair.ac.id/68392/), diakses pada tanggal 2 Mei 2018.

Bush, T. \& Mariane, C. 2006. Manajemen Strategi Kepemimpinan Pendidikan. Terjemah Farurrozi. Yogyakarta: IRCiSoD.

Farhati, F. \& Haryanto, F.1998. Karakteristik Pekerjaan, Dukungan Sosial dan Tingkat Burn-Out Pada Non Human Services Corporation. Jurnal Psikologi. No. 1. 1-12. Yogyakarta: Universitas Gajah Mada.

Fattah, N. 2008. Landasan Manajemen Pendidikan. Bandung: PT. REMAJA ROSDAKARYA.

Haryanti, R. 2013. Burnout Ditinjau dari Big Five Factor Personality Pada Karyawan Kantor Pos Pusat Malang. Jurnal Ilmiah Psikologi Terapan,01(02) 343-360. Dari http://ejournal.umm.ac.id/index.php/ jipt/article/ viewFile/1587/1694.

Hasibuan, M. 2016. Manajemen Sumber Daya Manusia. Jakarta: Bumi Aksara. 
Leksono, H, S. 2014. Kebosanan Kerja: Peningkatan Stres dan Penurunan Kinerja Karyawan Dalam Spesialisasi Pekerjaan. Jurnal JIBEKA Volume 8 No. 2 Agustus 2014 : 14 - 18 (Online), (lp3m.asia.ac.id/wp.../HendiSuryo-Leksono-JIBEKA-vol-8-no-2-Agustus-2014.pdf) diakses tanggal 3 Februari 2017.

Miles,M. B, Huberman,A.M, dan Saldana,J. 2014. Qualitative Data Analysis, A Methods Sourcebook, Edition 3. USA: Sage Publications. Terjemahan Tjetjep Rohindi Rohidi, UI-Press.

Mutiasari. 2010. Strategi Mengatasi Burnout di Tempat Kerja. Jurnal Pro Bisnis. No. 1. 40-47. Purwokerto : STIE Sastria Purwokerto.

Rosyid, H, F.1996. Burnout: Penghambat Produktifitas yang perlu di cermati. Jurnal Psikologi. No. 1. 0854-7108. Yogyakarta: Universitas Gajah Mada.

Sudjono, S. 2004. Manajemen Program Pendidikan ( Untuk Pendidikan Nonformal Dan Pengembangan Sumber Daya Manusia. Bandung. Falah Production

Sugiyono. 2013. Memahami Penelitian Kualitatif. Bandung: Alfabeta. 